Agnieszka SITKO-LUTEK, Monika JAKUBIAK

Uniwersytet Marii Curie-Skłodowskiej

Instytut Zarządzania

Zakład Zarządzania

agnieszka.sitko-lutek@poczta.umcs.lublin.pl,monika.jakubiak@umcs.pl

\title{
EMPLOYEES' SKILLS AND COGNITIVE STYLES IN THE CONTEXT OF SEX AND AGE
}

\begin{abstract}
Globalization, rapid development of technologies and everchanging surrounding environment determine the operation of modern organizations. Employees' competences, as well as their willingness for constant improvement, gain significance in such a context. The present paper discusses skills of innovative companies' employees and their learning styles in view of age and sex. The objective of the study was to identify and assess the influence of various independent features characterizing the employees upon their skills and learning styles. Research results enable recommendations for HR departments' employees to be made as regards management of diverse teams in particular (especially as far as age and sex are concerned).
\end{abstract}

Keywords: employees' skills, cognitive styles, employees' characteristics

\section{UMIEJĘTNOŚCI PRACOWNIKÓW I STYLE UCZENIA SIĘ W KONTEKŚCIE WIEKU I PŁCI ${ }^{1}$}

Streszczenie. Globalizacja, gwałtowny rozwój technologii i nieustanne zmiany w otoczeniu determinują funkcjonowanie współczesnych organizacji. Szczególnego znaczenia nabierają kompetencje pracowników, jak również wyrażanie przez nich chęci ciągłego doskonalenia. Problematyka prezentowanego opracowania dotyczy umiejętności pracowników innowacyjnych przedsiębiorstw oraz prezentowanych przez nich stylów uczenia, rozpatrywanych w kontekście wieku i płci. Celem badań była identyfikacja i ocena wpływu cech niezależnych charakteryzujących pracowników przedsiebiorstw na ich umiejętności oraz style uczenia. Wyniki badań predestynują do sformułowania rekomendacji dla pracowników działów HR odnośnie do zarządzania zróżnicowanymi (w szczególności pod względem wieku i płci) zespołami pracowników.

\footnotetext{
${ }^{1}$ Badania zrealizowano $\mathrm{w}$ ramach projektu pt. Potencjał kompetencyjny wybranych grup pracowników w aspekcie zarządzania różnorodnością w innowacyjnych przedsiębiorstwach (umowa nr UMO-2013/ 09/B/HS4/01307).
} 
Słowa kluczowe: umiejętności pracowników, style uczenia, cechy pracowników

\section{Introduction}

Diverse team management is indicated among challenges the modern companies are faced with. Demography, extending period of professional activity, and consecutive generations entering the labor market result in employees operating in diverse teams and workgroups. Management of such teams requires that both managers and HR department staff possess specific competences - openness, flexibility, understanding. As a consequence, managing modern organizations and their employees in a way translating diversity into an advantage instead of a source of losses or conflicts, seems critical.

\section{The subject and the literature}

Modern organizations operate in the state of constant change. Globalization, development of new technologies, employees' mobility, much shorter product life cycles are among the main causes of such a state. The literature of the subject highlights that people constitute the most critical capital of modern organizations. In knowledge and innovation-based economies, it is employees' competences, their skills, potential, and creativity that frequently offer a competitive edge. Due to rapid ageing of particular competences and emergence of additional ones, never before has the need for improvement and development been so clear. Modern managers and HRM experts have become aware that an investment in employees' development may result in achieving a lasting competitive edge ${ }^{2}$.

On the other hand, the literature of the subject emphasizes that maintaining such an edge cannot result solely from the resources at one's disposal. In the state of a constant change, organizations' success is determined by their ability to adapt swiftly i.e.: 1) to perceive and react to signals of a change, 2) by swift and frequent new, innovative actions, 3) ability to manage complex networks of numerous stakeholders, 4) ability to motivate employees and partners $^{3}$.

\footnotetext{
${ }^{2}$ Kramer M.R.: Creating shared value. "Harvard Business Review", Vol. 89(1/2), 2011; Crook T.R., Todd S.Y., Combs J.G., Woehr D.J., Ketchen D.J. Jr.: Does human capital matter? A meta-analysis of the relationship between human capital and firm performance. "Journal of Applied Psychology", Vol. 96(3), 2011.

${ }^{3}$ Reeves M., Deimler M.: Adaptability: The new competitive advantage. "Harvard Business Review", JulyAugust, 2011.
} 
Employees' motivation seems of vital importance from the point of view of the present study. This is due to the fact that currently, the level of motivation, involvement and job satisfaction is determined by factors other than financial ones. In order to ensure the organization benefits from highly qualified, competent and loyal staff, care for employees and their constant development is critical ${ }^{4}$. Investment in personnel's competences may and ought to constitute a vital element of organizations' motivational system ${ }^{5}$.

At present, motivating employees and developing an involved, loyal team poses a particular challenge for managers. This is a consequence of an increasing diversity of teams and the necessity for the adoption of a particular approach towards management of such.

The concept of diversity management belongs among the non-traditional branches of management. It reflects the current status of economy and society. HR managers should create a company that allows diverse employees to express themselves individually while maximizing their work competencies. Nowadays, managing diversified human resources is becoming an important component of building the successful strategy of a modern organization. In such organizations, the diversity of employees' potential constitutes an important value ${ }^{6}$. This is especially significant for innovative, global companies, which should look towards the future. Diversity leaders play a key role in the process of creating a successful organization ${ }^{7}$.

In the literature of the subject there are various definitions of the concept of diversity. In addition, diversity management is understood in very different ways. The understanding of the term depends on the country, the type of organization, its culture, as well as economic and social factors. Both wide and narrow approaches to diversity can be found in the literature of the subject ${ }^{8}$. The wide approach has several dimensions, e.g. age, gender, marital status, social status, sexual orientation, disability level, religion, personality, moral values, culture. The narrow approach, in turn, means that one or two dimensions are taken into consideration (e.g. gender and age). This is the approach to be used in the present paper.

As a result of prolonged professional activity and successive employee generations entering the labour market, the frequency managers deal with multi-generational teams has increased. Effective management of such teams requires particular skills so that the team's

\footnotetext{
${ }^{4}$ Bartkowiak G.: Dobrostan pracowników, poziom „zdrowia organizacji” a ich zadowolenie $\mathrm{z}$ pracy i zaangażowanie w realizację celów organizacji. Prace Naukowe Uniwersytetu Ekonomicznego, nr 223. Wrocław 2011.

${ }^{5}$ Woźniak J.: Współczesne systemy motywacyjne. Teoria i praktyka. PWN, Warszawa 2012.

${ }^{6}$ Armstrong C., Flood P., Guthrie J., Liu W., McCurtain S., Mkamwa T.: The impact of diversity and equality management of firm performance; beyond high performance work systems. "Human Resource Management", Vol. 49(6), 2010; Walczak W.: Zarządzanie różnorodnością jako podstawa budowania potencjału kapitału ludzkiego organizacji. „E-mentor”, nr 3(40), 2011, http://www.e-mentor.edu.pl/artykul/index/numer/40/id/840, 20.06.2016.

${ }^{7}$ Childs J.T. Jr. (ed.): Managing workforce diversity at IBM: A global HR topic that has arrived. "Human Resource Management", Vol. 44, Iss. 1, 2005.

${ }^{8}$ Rakowska A.: Managing Diverse Human Potential: Challenges Or Benefits for Organizations?, [in:] Dermol V., Rakowska A. (eds.): Strategic Approaches to Human Resources Management Practice. ToKnowPress, 2014, http://www.toknowpress.net/ ISBN/978-83-65020-00-0.pdf.
} 
potential is used to the fullest, and possible conflicts within the team are dealt with efficiently ${ }^{9}$. Misunderstandings and troublesome situations result from a stereotypical perception of other age groups. It may be associated with e.g. different approaches towards knowledge, ease of handling new technologies, means of communication, skills and experiences. Multi-generational teams' management requires considerable awareness on the part of managers, who ought to be able to notice and solve conflicts before they escalate, which would result in further cooperation in the particular team becoming impossible.

Despite the occurrence of rapid socio-economic changes in Europe and worldwide over the past several dozen years, we are still dealing with widespread stereotypisation with regards to sex. The following represent the most ubiquitous women's stereotypes 1) a woman is weak and submissive, 2) a woman is primarily a mother and a wife, financially dependent on the husband, 3) a woman is too emotional and incapable of making independent decisions ${ }^{10}$. Gender stereotypisation affects men as well. To a large degree, it also determines (frequently involuntarily) their life choices such as: educational profile, choice of profession, level of social, public or political activity.

Numerous studies in this field indicate that gender stereotypes are still widespread and deeply rooted in public awareness. Cultural norms, stereotypical perception of gender roles, and accepted social models result in women in European countries being less interested in the career of an entrepreneur and manager, and at the same time, less confident about their competences than $\operatorname{men}^{11}$. Female respondents evaluate their skills in establishing and managing businesses, lower than men $\mathrm{do}^{12}$. On the other hand, other studies indicate that women earn less because they seem to be punished for being a "good citizen" i.e. because they frequently pursue socially useful professions or manifest higher ethical standards ${ }^{13}$.

Social norms and the perception of gender roles in a particular society largely determine women's and men's professional activity and attitudes ${ }^{14}$. Researchers claim that these differences may be observed at a quite early stage, in young people-students. Studies of entrepreneurial attitudes conducted in four significantly different countries ${ }^{15}$ proved that female students made decisions regarding their prospective course of life on the basis of fears

\footnotetext{
${ }^{9}$ Rudolph C.W., Zacher H.: Intergenerational perceptions and conflicts in multi-age and multigenerational work environments. Facing the challenges of a multi-age workforce: A use-inspired approach. 2015.

${ }^{10}$ Buchowska N.: Relacja między realizacją praw kobiet a stereotypami płci w świetle standardów ONZ i Unii Europejskiej. "Nauka”, nr 2, 2013.

${ }^{11}$ Piacentini M.: Women Entrepreneurs in the OECD: Key Evidence and Policy Challenges, OECD Social, Employment and Migration Working Papers, No. 147. OECD Publishing, 2013; Estévez-Abe M.: Gender Bias in Skills and Social Policies: The Varieties of Capitalism Perspective on Sex Segregation. Oxford Journals, Social Sciences, Social Politics, Vol. 12, Iss. 2, 2005.

12 Thébaud S.: Gender and entrepreneurship as a career choice do self-assessments of ability matter? "Social Psychology Quarterly", Vol. 73(3), 2010.

${ }^{13}$ Grove W.A., Hussey A., Jetter M.: The gender pay gap beyond human capital heterogeneity in noncognitive skills and in labor market tastes. „Journal of Human Resources”, Vol. 46(4), 2011.

14 Shneor R., Camgöz S.M., Karapinar P.B.: The interaction between culture and sex in the formation of entrepreneurial intentions. "Entrepreneurship \& Regional Development", Vol. 25, Iss. 9-10, 2013.

${ }^{15}$ USA, China, Turkey, Belgium.
} 
and possible difficulties. On the other hand, male students were largely driven by their motivation for success. The motivation proved to positively determine entrepreneurial attitudes, while fears and barriers exerted a negative impact upon these ${ }^{16}$.

Research results indicate that stereotypes are not limited to a mere repetition of popular opinions regarding men and women, but have a significant influence upon decisions regarding activities undertaken by both sexes. Stereotypisation exerts the greatest impact upon women, and frequently prevents them from pursuing their rights and undertaking the same tasks men $\mathrm{do}^{17}$. As a consequence, women earn less even though they carry out similar duties and occupy similar positions then men do. The literature of the subject offers numerous examples where female managers are discriminated against with regards to sex and age ${ }^{18}$.

Therefore, eradicating gender stereotypes, whose aspects are discussed by the European parliament and UN, seems critical. The UN Charter indicates that sex may not constitute a criterion determining the scope of rights granted to any person. In conclusions to the Committee's report, numerous instances of negative gender stereotypisation are presented. These describe women as socially predestined for the role of a wife and mother, and men as sole providers, which frequently results in the lack of equal opportunities both at work and in daily life. EU member states are thus obliged to develop national documents and action plans facilitating equal treatment of men and women.

Globalization and changes within and without organizations result in companies' growing awareness of the requirement for constant development of employees' qualifications. This is a consequence of the need for the so-called soft competences such as interpersonal skills, teamwork, communication skills, flexibility, leadership, stimulation of development. However, it is hard skills such as technical knowledge and vocational skills which are perceived as more critical than the soft ones. Interestingly, such opinions are voiced by both young and senior employees. According to employers, interpersonal skills have gained importance and may be a decisive factor as far as prospective employment or promotion are concerned. Soft skills facilitate success in both personal and professional life ${ }^{19}$.

As a consequence, successful managers ought to be equipped with appropriate soft skills in order to support their subordinates. Trainings in these are beneficial for both of the involved parties. Employers may treat them as a vital element of a successful motivational system. Employees may regard them as a token of appreciation and an opportunity for development. A variety of tools may be applied to that effect, e.g. coaching and mentoring, frequently present in organizations in the form of support from experienced employees, superiors or HR department. Successful coaching offers tangible benefits by improving

16 Şeşen H., Pruett M.: Nascent Entrepreneurs: Gender, Culture, and Perceptions. "Journal of Women's Entrepreneurship and Education", No. 3-4, 2014.

${ }^{17}$ Młodożeniec M., Knapińska A.: Czy nauka wciąż ma męską płeć? Udział kobiet w nauce. "Nauka", nr 2, 2013.

${ }^{18}$ Jyrkinen M., McKie L.: Gender, age and ageism: experiences of women managers in Finland and Scotland. “Work, Employment \& Society”, Vol. 26(1), 2012.

${ }^{19}$ Heckman J.J., Kautz T.: Hard evidence on soft skills. "Labour Economics”, Vol. 19(4), 2012. 
employees', departments', and ultimately the organization's performance ${ }^{20}$. Such activities are crucial for the effective application of intellectual capital in business ${ }^{21}$.

Studies prove that an appropriate level of soft skills enables satisfactory subordinatesuperior relationship to be developed, which in turn, stimulates employees' belief in their efficiency, offers them motivation and boosts performance ${ }^{22}$.

Managerial skills associated with diversity management gain particular significance in such conditions. Those skills largely determine opportunities for development, which seems fundamental both for the organization and employees functioning in the changing labor market.

Apart from managers' and employees' skills, learning styles of individuals are also critical for the development of competence potential. The styles determine the way of thinking, identification of facts and assimilation of information.

The Cognitive Style Index (CSI) developed by Allison and Hayes ${ }^{23}$ was decided to be used in the present paper. CSI describes the way a person thinks, perceives and remembers information. CSI is also known as an important concept in the areas of education and management. Knowledge of an individual's cognitive style can be useful in HRM processes, e.g. selection, placement, motivation and development.

Allinson \& Hayes identified five notional learning styles. At the extremes intuition and analysis (intuitive and analytic styles) can be found. However, a cognitive style often involves elements of both intuition and analysis. In the middle of the continuum, there is the adaptive style, which implies a balanced blend of the two cognitive modes ${ }^{24}$. The quasi-intuitive style and quasi-analytical styles neighbor the adaptive style.

\footnotetext{
${ }^{20}$ Hagen M.: The wisdom of the coach: A review of managerial coaching in the Six Sigma context. "Total Quality Management", Vol. 21(8), 2010; Longenecker C.O.: Coaching for better results: key practices of high performance leaders. "Industrial and Commercial Training", Vol. 42, Iss. 1, 2010; Heathfield S.M.: Use Coaching to Improve Employee Performance, https://www.the balance.com/performance-improvementstrategies-1918714, 20.06.2016; Joo B.K.B., Sushko J.S., McLean G.N.: Multiple faces of coaching: Manageras-coach, executive coaching, and formal mentoring. "Organization Development Journal", Vol. 30(1), 2012.

${ }^{21}$ Jelínková E., Jiřincová M.: Diversity Management as a Tool of Managing Intellectual Capital. "Journal of Competitiveness", Vol. 7, Iss. 4, 2015.

22 Walumbwa F.O., Hartnell C.A.: Understanding transformational leadership-employee performance links: The role of relational identification and self-efficacy. "Journal of Occupational and Organizational Psychology", Vol. 84(1), 2011.

${ }^{23}$ Allinson Ch., Hayes J.: The Cognitive Style Index. Technical Manual and User Guide. Pearson, 2012.

${ }^{24}$ Ibidem.
} 


\section{Methods of research}

Empirical studies were conducted by means of a diagnostics poll method with the use of a questionnaire technique. The first part of the questionnaire pertained to respondents' skills, including those crucial from the point of view of professional responsibilities and development opportunities. Competences' areas were selected on the basis of literature review. The second part of the questionnaire encompassed learning styles presented by respondents.

Empirical data was collected in the course of studies conducted in Poland in 2015 among 1276 employees of innovative companies. The data was compiled in contingency tables, which were further analyzed statistically. The chi-square test was applied due to the character of the variables. Differences amounting to $p<0,05$ were determined as being statistically significant.

As regards the structure of respondents' sex, woman constitutes slight majority of them $(52 \%)$.

Further analyses taking respondents' age into consideration were conducted with regards to five age groups, in accordance with their distribution outlined in Fig. 1. The majority of respondents $(60 \%)$ represented the group of up to 39 years of age. Seniors aged 60 and above were the least numerous group (4\%).

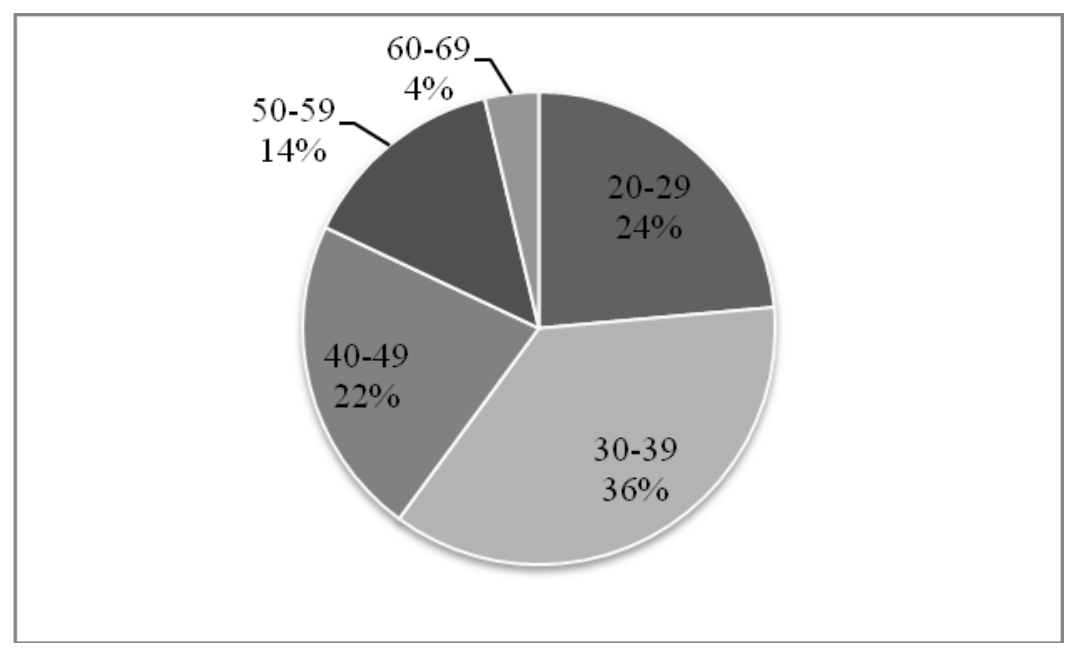

Fig. 1. Respondents' age structure $(\% ; \mathrm{N}=1276)$

Source: Authors' own study.

Respondents' structure with regards to their position in the organization is outlined in Fig. 2. The majority of respondents occupied the position of a specialist (58\%), and every fourth of an executive. 


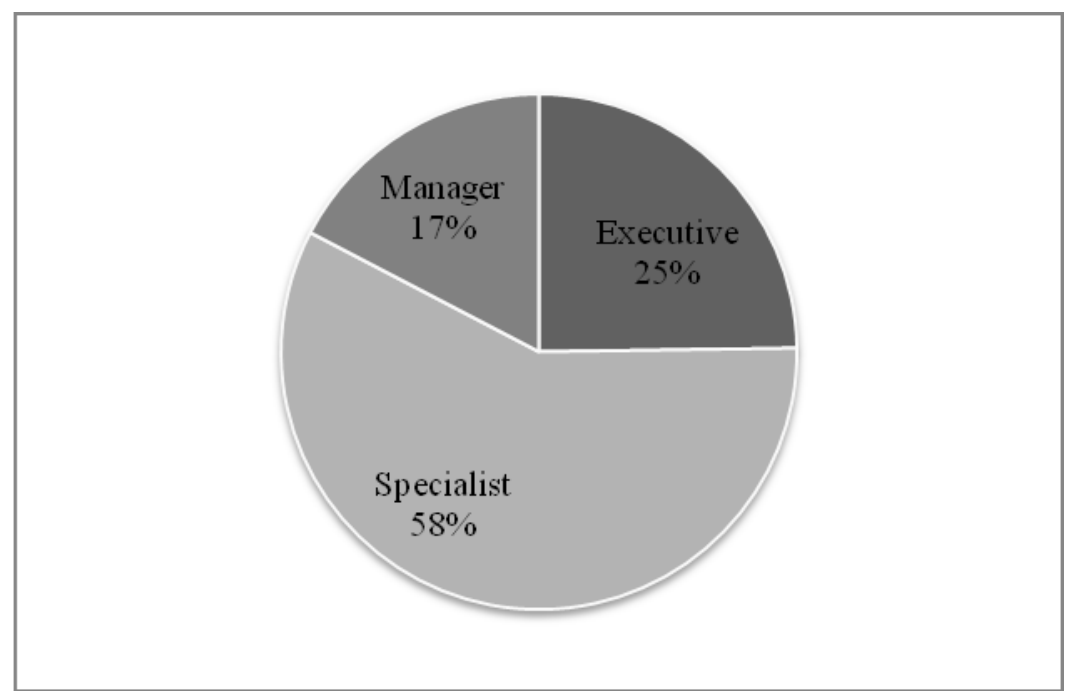

Fig. 2. The positions held by respondents $(\% ; \mathrm{N}=1276)$

Source: Authors' own study.

\section{Skills of respondents vs. their sex and age}

When searching for factors determining respondents' self-assessment with regards to their competences, answers were analyzed in this respect and their sex and age were taken into account as well.

Table 1

Competences vs. respondents' sex (\%)

\begin{tabular}{|c|c|c|c|c|}
\hline Respondents' competences & $\begin{array}{c}\text { Woman } \\
(n=658)\end{array}$ & $\begin{array}{c}\text { Man } \\
(n=618)\end{array}$ & $\mathbf{X}^{2}$ & Cramer's V \\
\hline Own workload management* & 55.4 & 44.6 & 14.15 & 0.11 \\
\hline Stress management* & 47.9 & 52.1 & 4.1 & 0.06 \\
\hline Learning & 49.3 & 50.7 & 2.23 & 0.04 \\
\hline Career management* & 44.8 & 55.2 & 3.91 & 0.06 \\
\hline Interpersonal communication* & 62.0 & 38.0 & 30.92 & 0.16 \\
\hline Resolution of conflicts* & 45.7 & 54.3 & 4.67 & 0.06 \\
\hline Cooperation with representatives of other cultures & 57.5 & 42.5 & 0.58 & 0.02 \\
\hline Leadership, leveraging & 43.3 & 56.7 & 3.13 & 0.05 \\
\hline Cooperation with people of all ages & 54.0 & 46.0 & 2.38 & 0.04 \\
\hline Cooperation with the opposite sex & 45.8 & 54.2 & 2.98 & 0.05 \\
\hline Swift adaptation to new conditions & 52.5 & 47.5 & 0.27 & 0.01 \\
\hline Mobilization to long-term work effort & 54.2 & 45.8 & 1.12 & 0.03 \\
\hline Ability to carry out duties of others and one's own & 55.2 & 44.8 & 1.5 & 0.03 \\
\hline Creative thinking* & 45.2 & 54.8 & 9.68 & 0.09 \\
\hline
\end{tabular}

Notes: *- statistically significant differences (test $\mathrm{X}^{2} ; \mathrm{df}=1 ; \mathrm{X}^{2}$ critical $=3.84 ; \mathrm{p}<0.05$ )

Source: Authors' own findings.

Table 1 presents respondents' answers regarding their strengths. Sex diversified respondents' answers in 4 out of 6 analyzed competences (43\%). Women evaluated their competences in interpersonal communication and own workload management significantly 
higher. On the other hand, men assessed their career management, creative thinking, resolution of conflicts, and stress management considerably higher.

When analyzing the impact of respondents' age upon their self-assessment of skills, statistically significant differences were observed in 6 out of 14 skills (Fig. 3).

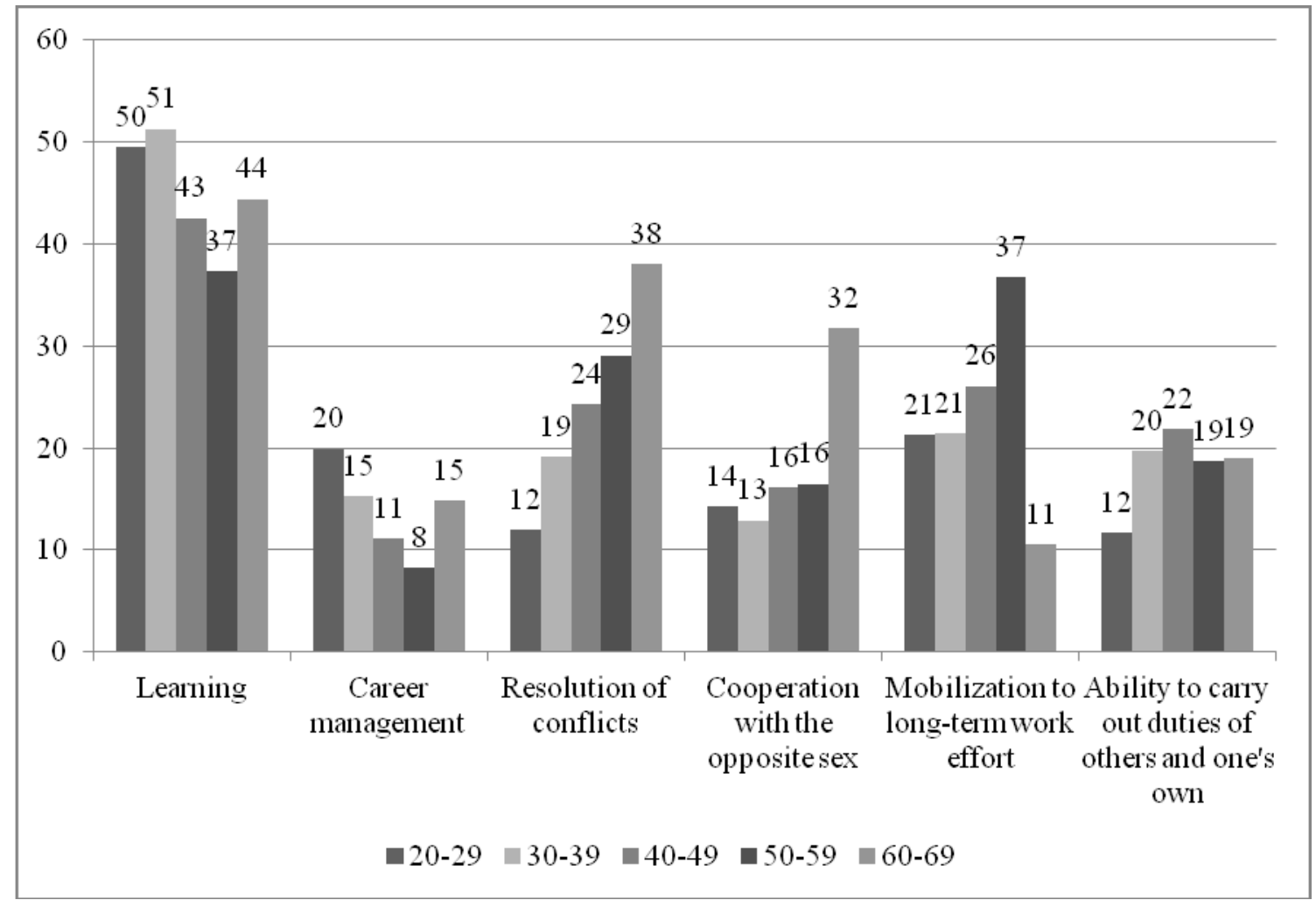

Notes: test $\mathrm{X}^{2} ; \mathrm{df}=4 ; \mathrm{X}^{2}$ critical $=9.49 ; \mathrm{p}<0.05$

Fig. 3. Respondents' skills vs. respondents' age (\%, statistically significant differences) Source: Authors' own findings.

When analyzing respondents' answers, regardless of their age, learning may be considered their strength. Every second respondent below 39 years of age declared the possession of the skill.

Remaining skills were evaluated lower. Problem- solving and cooperation with other sexes were declared frequently by seniors (60-69 years of age). Mobilization for prolonged work periods was declared the most frequently by those aged 50-59.

Own career management is the skill assessed the lowest. Only one in five of respondents aged 20-29 selected this skill. The remaining age groups selected the skill even less frequently. 


\section{Cognitive styles presented by respondents}

Table 2 features cognitive styles in the context of respondents' sex. Results' analysis indicated that it influences cognitive styles with regards to the quasi intuitive style. The style is present in women more frequently (14\% vs. 9.5\%). On the other hand, the analyst style is represented by men more often $(36.7 \%$ vs. $28.3 \%)$.

Table 2

Cognitive style vs. respondents' sex (\%)

\begin{tabular}{|l|c|c|c|c|}
\hline Cognitive style & Woman $(\mathbf{n}=\mathbf{6 5 8})$ & Man $(\mathbf{n}=\mathbf{6 1 8})$ & $\mathbf{X}^{\mathbf{2}}$ & Cramer's V \\
\hline Intuitive & 3.8 & 3.2 & 0.3 & 0.02 \\
\hline quasi intuitive* & 14.0 & 9.5 & 6.01 & 0.07 \\
\hline Adaptive & 22.9 & 19.9 & 1.75 & 0.04 \\
\hline quasi analyst & 31.0 & 30.6 & 0.03 & 0.00 \\
\hline analyst* & 28.3 & 36.7 & 10.43 & 0.09 \\
\hline
\end{tabular}

Notes: * statistically significant differences (test $\mathrm{X}^{2} ; \mathrm{df}=1 ; \mathrm{X}^{2}$ critical $=3,84 ; \mathrm{p}<0,05$ ).

Source: Authors' own findings.

Statistically significant differences were observed in case of quasi styles i.e. the ones manifesting tendencies of the intuitive or analyst styles. Women tend to make decisions with the view of the whole situation. When learning, they pay particular attention to the issue as a whole and are able to internalize several details at the same time. On the other hand, men concentrate on individual details. When learning, they internalize subsequent fragments in a logical sequence.

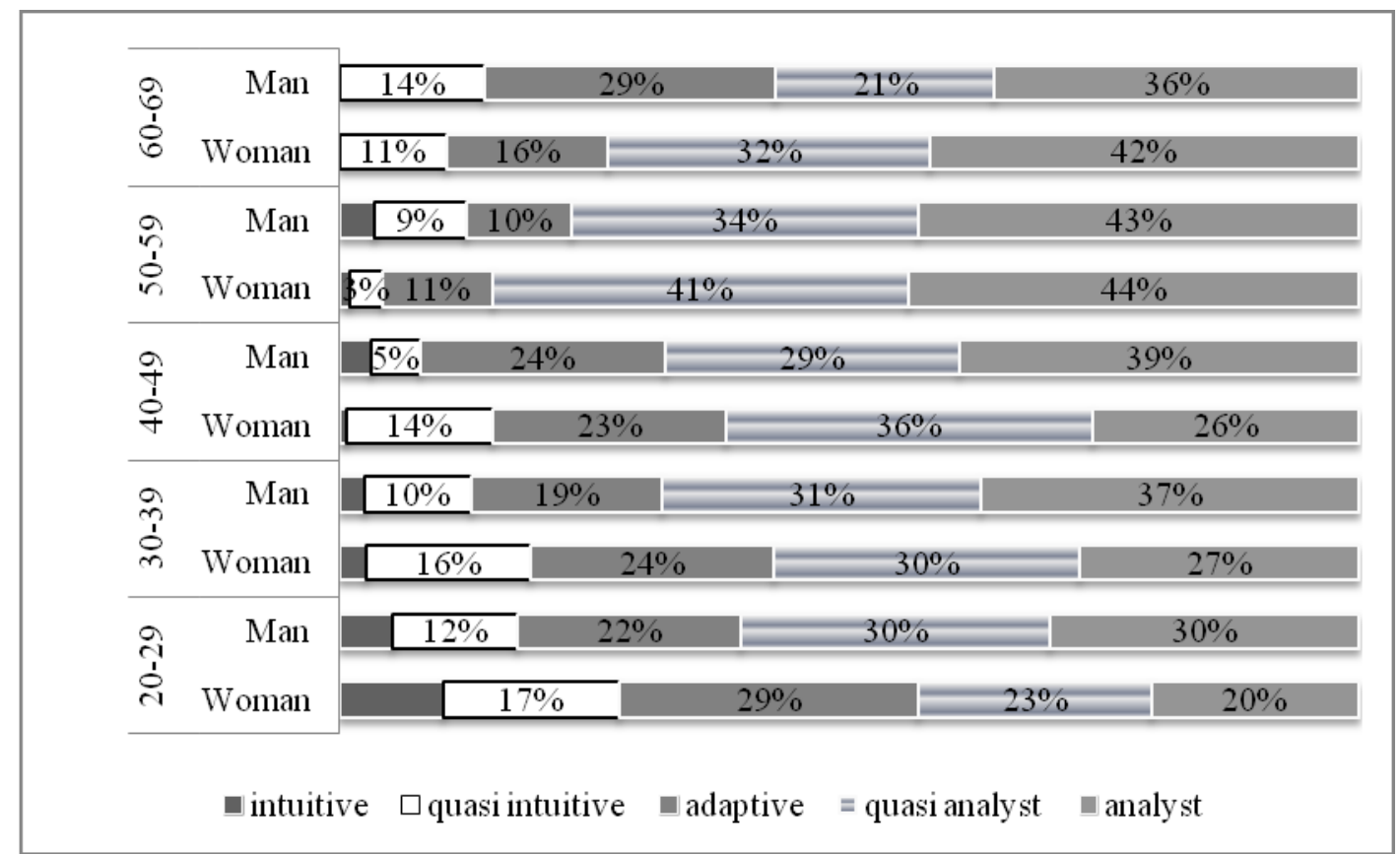

Fig. 4. The structure of cognitive styles' distribution with regards to sex and age Source: Authors' own findings. 
When considering the relationship between sex and respondents' cognitive styles in individual age groups, statistically significant differences were observed among those representing younger age groups. The diversification is very distinct in case of the analyst style, prevalent among men in 20-49 age groups (Fig. 4).

Statistically significant differences were observed in the structure of 20-29 year olds (Fig. 5). The analyst and quasi analyst styles were represented by men more frequently. On the other hand, the remaining styles were present in women more often.

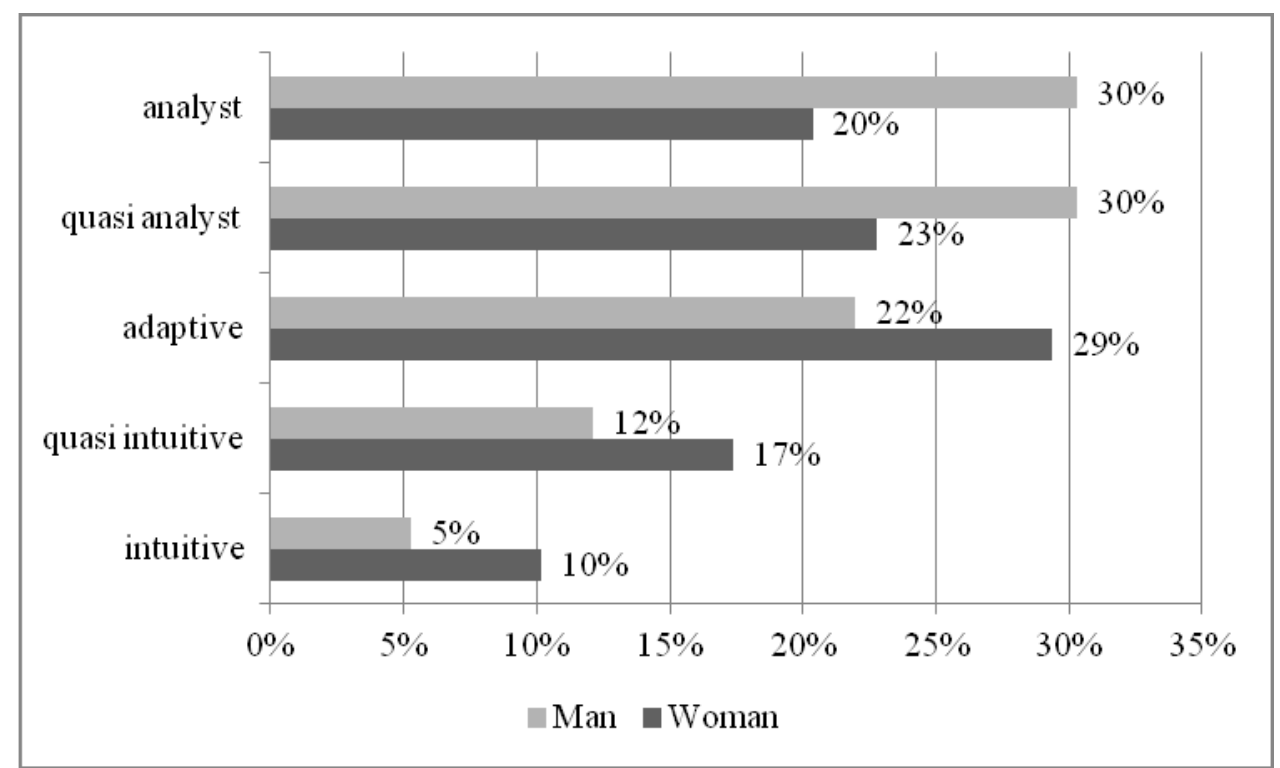

Notes: test $\mathrm{X}^{2} ; \mathrm{df}=4 ; \mathrm{X}^{2}$ critical $=9.49 ; \mathrm{p}<0.05$.

Fig. 5. Cognitive style represented by respondents in the age group 20-29 years (\%, statistically significant differences)

Source: Authors' own findings.

\section{Disscussion and conclusions}

The issue of the present paper pertains to skills and learning styles of innovative companies' employees, which were analyzed in the context of sex and age. The literature of the subject emphasizes that modern organizations must deal with increasingly diversified teams. There exist several sources of the diversity. However, due to the limited scope of the paper, two aspects i.e. sex, and age, became the key focus.

In search for answers to questions regarding the impact of independent variables characterizing respondents upon the self-assessment of their skills and represented learning styles, a survey among 1276 employees of innovative companies was conducted.

Results of the analyses indicated that respondents' sex and age have significant impact upon the declared skills, and also differentiate learning styles. 
Women assessed their interpersonal competences and own workload management significantly higher than men did. These skills are stereotypically described as "feminine". On the other hand, men evaluated their skills in career management, creative thinking, resolution of conflicts, and stress management considerably higher. These areas are perceived as requiring more rational thinking, composure, deduction, which are stereotypically associated with masculinity.

These results were reflected in the assessment of the influence of respondents' sex upon learning styles. It was observed that the quasi intuitive style was manifested by women, and the analyst style by men significantly more frequently.

Results of the current study correspond with findings present in the literature worldwide. The findings observe that the assessment of women's competences is partly determined by social expatiations. However, it is also a result of women's belief in their strengths and weaknesses $^{25}$. To a large extent, women perceive themselves as more emotional than rational, and frequently give way to men of their own free will. There is no harm in it if this is done consciously. However, women frequently find themselves under social pressure, and their choices are made under it. It is particularly difficult if they must choose between family and profession. Frequently, the work-family conflict prevents women from achieving satisfaction from carrying out their duties ${ }^{26}$.

Respondents' age determined the assessment of competences in 6 of the analyzed areas. Learning can be considered respondents' strength. The skill is undeniably crucial in knowledge-based economy and prevalent life-long learning, where constant development is highlighted as a vital aspect of life.

Research results indicated that conflict-solving improves with age. The youngest among the respondents assessed the skill the lowest (only 12\% of the 20-29 year olds consider it a strength). On the other hand, representatives of the eldest age group (38\%) assessed it the highest. Therefore, the thesis that competences resulting from a person's experience are developed with age has been verified.

When considering respondents competences in the context of age, it was observed that the skill of own career management was evaluated the lowest. Every fifth respondent of the youngest age group selected it as their strength. The remaining respondents assessed the skill even lower. However, in the ever-changing labor market, where careers frequently follow the sinusoid rather than a growing curve, such skills are worth developing.

\footnotetext{
${ }^{25}$ Thébaud S.: op.cit.; Grove W.A., Hussey A., Jetter M.: op.cit.; Piacentini M.: op.cit.

${ }^{26}$ Hwang W., Ramadoss K.: The Job Demands-Control-Support Model and Job Satisfaction Across Gender. The Mediating Role of Work-Family Conflict. "Journal of Family Issues”, http://jfi.sagepub.com/content/early/ 2016/05/06/0192513X16647983.full.pdf+html, 12.09.2016.
} 
When analyzing the sex-cognitive style relationship in individual categories, statistically significant differences were observed among the younger age groups. In case of the analyst style, prevalent among 20-49-years-of-age men, the greatest diversification was observed. Cognitive styles in senior age groups were not so overtly related to sex. Therefore, it can be said that with age, women follow intuition less and make a rational analysis of information more frequently.

To sum up, research results seem to confirm the impact of employees' sex and age upon their skills and cognitive styles.

Research results enable recommendations for HR departments' employees to be made as regards management of diverse teams in particular (especially as far as age and sex are concerned).

Management of diverse teams requires a greater degree of awareness from managers enabling them to motivate employees to achieve better results and improve their qualifications. When working with diverse teams, managers ought to notice and solve conflicts before they escalate and make further cooperation impossible.

Managers and HR experts ought to be aware of the fact that perceiving a particular person in light of a particular generation or sex may be a grave mistake. Employees require an individual approach, one which would take their characteristics, predispositions, experiences, values and skills into consideration. Individual talents ought to be searched for in any team, regardless of the members' age and sex. In order to ensure a proper development of the organization, effective motivational systems ought to be established. These ought to include development programs suited to employees' needs. Managers cannot forget than they ought to constantly develop their skills as well in order to manage diverse team as efficiently as possible.

Current analyses encompass only two of the numerous aspects of diversity present in organizations. Due to the limited scope of the present study, sex and age became the key focus, and other variables characterizing employees of modern organizations were disregarded. Further studies in the subject, ones which would expand on the issue of diversity and analyze e.g. education, social background, and employees' values and beliefs, are required. 


\section{Bibliografia}

1. Allinson Ch., Hayes J.: The Cognitive Style Index. Technical Manual and User Guide. Pearson, 2012.

2. Armstrong C., Flood P., Guthrie J., Liu W., McCurtain S., Mkamwa T.: The impact of diversity and equality management of firm performance; beyond high performance work systems. "Human Resource Management", Vol. 49(6), 2010.

3. Bartkowiak G.: Dobrostan pracowników, poziom ,zdrowia organizacji” a ich zadowolenie z pracy i zaangażowanie w realizację celów organizacji. Prace Naukowe Uniwersytetu Ekonomicznego, nr 223. Wrocław 2011.

4. Buchowska N.: Relacja między realizacją praw kobiet a stereotypami płci w świetle standardów ONZ i Unii Europejskiej. "Nauka", nr 2, 2013.

5. Childs J.T. Jr. (ed.): Managing workforce diversity at IBM: A global HR topic that has arrived. "Human Resource Management", Vol. 44, Iss. 1, 2005.

6. Crook T.R., Todd S.Y., Combs J.G., Woehr D.J., Ketchen D.J. Jr.: Does human capital matter? A meta-analysis of the relationship between human capital and firm performance. "Journal of Applied Psychology", Vol. 96(3), 2011.

7. Estévez-Abe M.: Gender Bias in Skills and Social Policies: The Varieties of Capitalism Perspective on Sex Segregation. Oxford Journals, Social Sciences, Social Politics, Vol. 12, Iss. 2, 2005.

8. Grove W.A., Hussey A., Jetter M.: The gender pay gap beyond human capital heterogeneity in noncognitive skills and in labor market tastes. „Journal of Human Resources", Vol. 46(4), 2011.

9. Hagen M.: The wisdom of the coach: A review of managerial coaching in the Six Sigma context. "Total Quality Management”, Vol. 21(8), 2010.

10. Heathfield S.M.: Use Coaching to Improve Employee Performance, https://www.the balance.com/performance-improvement-strategies-1918714, 20.06.2016.

11. Heckman J.J., Kautz T.: Hard evidence on soft skills. "Labour Economics", Vol. 19(4), 2012.

12. Howells J., Ramlogan R., Cheng S.L.: Innovation and university collaboration: paradox and complexity within the knowledge economy. "Cambridge Journal of Economics", Vol. 36, Iss. 3, 2012.

13. Hwang W., Ramadoss K.: The Job Demands-Control-Support Model and Job Satisfaction Across Gender. The Mediating Role of Work-Family Conflict. "Journal of Family Issues", http://jfi.sagepub.com/content/early/2016/05/06/0192513X16647983.full.pdf + html, 12.09.2016.

14. Jelínková E., Jiřincová M.: Diversity Management as a Tool of Managing Intellectual Capital. "Journal of Competitiveness", Vol. 7, Iss. 4, 2015. 
15. Joo B.K.B., Sushko J.S., McLean G.N.: Multiple faces of coaching: Manager-as-coach, executive coaching, and formal mentoring. "Organization Development Journal", Vol. 30(1), 2012.

16. Jyrkinen M., McKie L.: Gender, age and ageism: experiences of women managers in Finland and Scotland. "Work, Employment \& Society", Vol. 26(1), 2012.

17. Kirton G., Greene A.M.: The dynamics of managing diversity: A critical approach. Routledge, 2015.

18. Kramer M.R.: Creating shared value. "Harvard Business Review”, Vol. 89(1/2), 2011.

19. Longenecker C.O.: Coaching for better results: key practices of high performance leaders. "Industrial and Commercial Training", Vol. 42, Iss. 1, 2010.

20. Loza E.: Female Entrepreneurship Theory: A Multidisciplinary Review of Resources. "Journal of Women's Entrepreneurship and Education", Iss.1-2, 2011.

21. Młodożeniec M., Knapińska A.: Czy nauka wciąż ma męską płeć? Udział kobiet w nauce. "Nauka", nr 2, 2013.

22. Piacentini M.: Women Entrepreneurs in the OECD: Key Evidence and Policy Challenges, OECD Social, Employment and Migration Working Papers, No. 147. OECD Publishing, 2013.

23. Rakowska A.: Managing Diverse Human Potential: Challenges Or Benefits for Organizations?, [in:] Dermol V., Rakowska A. (eds.): Strategic Approaches to Human Resources Management Practice. ToKnowPress, 2014, http://www.toknowpress.net/ ISBN/978-83-65020-00-0.pdf.

24. Reeves M., Deimler M.: Adaptability: The new competitive advantage. "Harvard Business Review”, July-August, 2011.

25. Robles M.M.: Executive perceptions of the top 10 soft skills needed in today's workplace. "Business Communication Quarterly", Vol. 75(4), 2012.

26. Rudolph C.W., Zacher H.: Intergenerational perceptions and conflicts in multi-age and multigenerational work environments. Facing the challenges of a multi-age workforce: A use-inspired approach. 2015.

27. Şeşen H., Pruett M.: Nascent Entrepreneurs: Gender, Culture, and Perceptions. "Journal of Women's Entrepreneurship and Education”, No. 3-4, 2014.

28. Shneor R., Camgöz S.M., Karapinar P.B.: The interaction between culture and sex in the formation of entrepreneurial intentions. "Entrepreneurship \& Regional Development", Vol. 25, Iss. 9-10, 2013.

29. Thébaud S.: Gender and entrepreneurship as a career choice do self-assessments of ability matter? "Social Psychology Quarterly”, Vol. 73(3), 2010.

30. Walczak W.: Zarządzanie różnorodnością jako podstawa budowania potencjału kapitału ludzkiego organizacji. „E-mentor”, nr 3(40), 2011, http://www.e-mentor.edu.pl/artykul/ index/numer/40/id/840, 20.06.2016. 
31. Walumbwa F.O., Hartnell C.A.: Understanding transformational leadership-employee performance links: The role of relational identification and self-efficacy. "Journal of Occupational and Organizational Psychology", Vol. 84(1), 2011.

32. Woźniak J.: Współczesne systemy motywacyjne. Teoria i praktyka. PWN, Warszawa 2012.

33. http://www.europarl.europa.eu/sides/getDoc.do?pubRef=-//EP//TEXT+REPORT+A72012-0401+0+DOC+XML+V0//E.

34. http://epp.eurostat.ec.europa.eu.

35.http://www.hfhrpol.waw.pl/pliki/Karta_Narodow_Zjednoczonych.pdf.

36. http://www.stat.gov.pl.

37.http://www.un.org/en/events/women/iwd/2010/documents/beijing15_onepage_en.pdf. 